\title{
Prevalence of other associated risk factors of Cardiovascular Disease among Hypertensive patients in Eastern Nepal.
}

\author{
Buna Bhandari ${ }^{1}$, Mahesh Bhattarai ${ }^{2}$, Manjul Bhandari ${ }^{3}$, Anup Ghimire ${ }^{4}$, Paras Kumar Pokharel ${ }^{4}$ \\ ${ }^{1}$ Department of Community Medicine, Kathmandu Medical College \\ ${ }^{2}$ Department of Cardiology, National Academy of Medical Sciences \\ ${ }^{3}$ Sunsari District Hospital, Inarwa \\ ${ }^{4}$ School of Public Health and Community Medicine, B.P. Koirala Institute of Health Sciences
}

\section{Citation}

Buna Bhandari, Mahesh Bhattarai,Manjul Bhandari, Prevalence of other associated risk factors of Cardiovascular Disease among Hypertensive patients in Eastern Nepal. Nepalese Heart Journal 2014;11(1): 27-31.

\section{Keywords}

Cardiovascular disease, Hypertension, Risk factors

\section{INTRODUCTION}

Cardiovascular disease (CVD) is the most important cause of death worldwide, accounting for $48 \%$ of death due to Non communicable diseases in 2012.1 Hypertension is one of the important risk factor for CVD, causing $45 \%$ of global CVD morbidity and mortality.2 Along with other major chronic disease risk factors such as smoking, diabetes, and

\begin{abstract}
Background and Aims : Cardiovascular disease is the leading cause of death worldwide. Hypertension is one of the most important risk factors for Cardiovascular Diseases which cause $45 \%$ of global cardiovascular morbidity and mortality. Hypertension, along with other risk factors such as smoking, diabetes and obesity, is an emerging epidemic in many developing countries. This study aimed to find out the prevalence of other associated conventional risk factors of cardiovascular disease among hypertensive patients.
\end{abstract}

Methods: Community based cross sectional study was conducted among 154 hypertensive patients over age 35yrs in Dharan Municipality. Data were collected by face to face interview method using structured questionnaire then analyzed by using descriptive and inferential statistics.

Results: Around 29\% hypertensive patients were between the age of 45 - 55 yrs and above 65 years. Prevalence of obesity was significantly higher $70.8 \%$. Similarly, 46.8\% had habit of taking high salt diet and $58.4 \%$ were taking high fat diet. Likewise, less physically active people were $58.4 \%$ and $64.9 \%$ were consuming alcohol regularly. Whereas $42.9 \%$ were smoker and $48.7 \%$ had stressful life. Moreover, this study also showed $46.1 \%$ had uncontrolled blood pressure in this hypertensive group.

Conclusion: Cardiovascular Disease risk factors are highly prevalent among the hypertensive patients in this study.

\section{Corresponding author}

Buna Bhandari

Department of Community Medicine, Kathmandu, Nepal

Kathmandu Medical College

Email:bhbuna@gmail.com 
obesity, hypertension is an emerging epidemic in many lower- and middle-income countries.3,4 Heart disease is estimated to increase continuously during the next few decades. In fact, the number of people over 60 years of age is expected to double by 2025 and to triple by 2050 globally.5 Due to economic growth and globalization, CVD is increasing even in the developing countries where they were labeled as the diseases of affluence.6 In Asian countries, as a result of economic growth, the prevalence of obesity and diabetes are increasing. 7 Moreover, western lifestyle, sedentary habits and high fat diet leads to increased cardiovascular disease. 8 Smoking is a potent risk factor not only for coronary artery disease but also for stroke, the population-attributable fraction of smoking for CVD is high, at $30 \%$, second only to high blood pressure.9,10 The population-attributable fraction of hypertension for CVD is as high as $60 \%$ in Asian countries. 11

According to the World Health Organization's recent update; ${ }^{12}$ diabetes, hypertension, and obesity are important risk factors for cardiovascular deaths in the world. This study aimed to find out the prevalence of other associated cardiovascular risk factors among hypertensive patients of Dharan municipality, Eastern part of Nepal.

\section{METHODS}

Community based descriptive cross sectional study was conducted in Dharan municipality, Nepal. Study population were 154 , which was calculated assuming a prevalence of the risk factors of $50 \%$ with a $95 \%$ cofidence interval where allowable error was taken as $16 \%$ of Prevalence. Known cases of Hypertension, diagnosed in BP Koirala Institue of Health Sciences (BPKIHS) were included in the study. First, the total number of hypertensive patient who visited during the period of one year in BP Koirala Institue of Health Sciences were listed from the register and by using simple random sampling lottery method, the required number of sample was selected. Data was collected by face to face interview method and measurement of blood pressure, height and weight was done. Structured questionnaire was completed on behalf of each participants. The collected data was edited, coded and categorized. Data was entered into Microsoft Excel and then analyzed in the Statistical Package for Social Sciences 16. For descriptive analysis, mean, standard deviation and median was calculated. Categorical variables were compared using the nonparametric Chisquares tests.

\section{RESULTS}

This community based cross sectional descriptive study included one hundred and fifty four hypertensive patients aged over 35 yrs of Dharan municipality.
Sociodemographic variables : The median age of the respondent was 54.5 years. Twenty Nine percent were between the age of $45-55$ years and 65 years and above, and $53.9 \%$ were female. More than half of the respondents 85 $(55 \%)$ were Hindu whereas (39\%) belong to disadvantaged janajatis. Literate were 88 (57\%), among them, $46.5 \%$ were educated up to secondary level. Sixty nine percentages of them had employment. Farming was common occupation for $44.9 \%$ of the resondents as presented in Table 1 .

Table 1. Distribution of socioeconomic characteristics of respondents

\begin{tabular}{|c|c|c|c|}
\hline $\begin{array}{l}\text { Character- } \\
\text { istics }\end{array}$ & Categories & Number & $\%$ \\
\hline \multirow{4}{*}{ Age in years } & $35-45$ & 32 & 20.8 \\
\hline & $45-55$ & 45 & 29 \\
\hline & $55-65$ & 32 & 20.8 \\
\hline & $65+$ & 45 & 29 \\
\hline Median age & 54.5 & & \\
\hline \multirow{2}{*}{ Sex } & Male & 71 & 46.1 \\
\hline & Female & 83 & 53.9 \\
\hline \multirow{3}{*}{ Caste } & Disadvantaged Janajatis & 60 & 39 \\
\hline & Uupper caste group & 59 & 38.5 \\
\hline & $\begin{array}{l}\text { Relatively advantaged } \\
\text { janajatis and dalit }\end{array}$ & 35 & 22.5 \\
\hline \multirow{4}{*}{ Religion } & Hindu & 85 & 55.2 \\
\hline & Christian & 30 & 11.0 \\
\hline & Kirat & 22 & 19.5 \\
\hline & Buddhist & 17 & 14.3 \\
\hline \multirow{2}{*}{$\begin{array}{l}\text { Educational } \\
\text { Status }\end{array}$} & Literate & 88 & 57.1 \\
\hline & Illiterate & 66 & 42.9 \\
\hline \multirow{2}{*}{$\begin{array}{l}\text { Educational } \\
\text { level }\end{array}$} & Below Primary level & 31 & 20.1 \\
\hline & Above primary level & 57 & 79.9 \\
\hline \multirow{2}{*}{$\begin{array}{c}\text { Marital } \\
\text { status }\end{array}$} & Married & 121 & 78.6 \\
\hline & Widow & 33 & 21.4 \\
\hline \multirow{2}{*}{$\begin{array}{c}\text { Current } \\
\text { occupation }\end{array}$} & Unemployed & 47 & 30.5 \\
\hline & Employed & 107 & 69.5 \\
\hline \multirow{4}{*}{$\begin{array}{c}\text { Main } \\
\text { occupation }\end{array}$} & Farmer & 48 & 31.2 \\
\hline & Service holder & 22 & 14.3 \\
\hline & Business & 31 & 20.1 \\
\hline & Others & 6 & 3.9 \\
\hline
\end{tabular}


Prevalence of CVD risk factors:. Obesity was significantly $(\mathrm{p}=<0.001)$ higher $70.8 \%$ in the study population. Among hypertensive patient most of them 63\% (97) had family history of hypertension which was significant $(\mathrm{p}=0.001)$. Habits of taking high salt diet was found in $46.8 \%$ but habit of taking high fat diet was significantly $(p=0.036)$ higher in $58.4 \%$. Likewise less physical active people were significantly ( $p=0.036$ ) higher $58.4 \%$ in this hypertensive group. Furthermore alcoholism was also found significantly ( $p=<0.001)$ higher $64.9 \%$, in contrast to smoking $(42.9 \%)$ and stress $(48.7 \%)$ which were not significant. Similarly $46.1 \%$ of them had uncontrolled blood pressure as mentioned in table 2 .

Table 2. Distribution of prevalence of other associated cardiovascular risk factors $(\mathrm{n}=154)$

\begin{tabular}{|c|c|c|c|}
\hline Characteristics & Categories & Frequency & p. Value ${ }^{\mathrm{a}}$ \\
\hline \multirow{4}{*}{ Age } & $35-45$ & $32(20.8)$ & \multirow{4}{*}{0.222} \\
\hline & $45-55$ & $45(29)$ & \\
\hline & $55-65$ & $32(20.8)$ & \\
\hline & $65+$ & $45(29)$ & \\
\hline \multirow{2}{*}{ Obesity } & Obese & $109(70.8)$ & \multirow{2}{*}{$<0.001^{*}$} \\
\hline & Non obese & $45(29.2)$ & \\
\hline \multirow{2}{*}{ High salt diet } & Yes & $72(46.8)$ & \multirow{2}{*}{0.420} \\
\hline & No & $82(53.2)$ & \\
\hline \multirow{2}{*}{ High fat diet } & Yes & $90(58.4)$ & \multirow{2}{*}{$0.036^{*}$} \\
\hline & No & $64(41.6)$ & \\
\hline \multirow{2}{*}{$\begin{array}{c}\text { Less Physical } \\
\text { activity }\end{array}$} & Yes & $90(58.4)$ & \multirow{2}{*}{$0.036^{*}$} \\
\hline & No & $64(41.6)$ & \\
\hline \multirow{2}{*}{ Alcoholism } & Yes & $100(64.9)$ & \multirow{2}{*}{$<0.001 *$} \\
\hline & No & $54(35.1)$ & \\
\hline \multirow{2}{*}{ Smoking } & Yes & $66(42.9)$ & \multirow{2}{*}{0.076} \\
\hline & No & $88(57.1)$ & \\
\hline \multirow{2}{*}{ Stress } & Yes & $75(48.7)$ & \multirow{2}{*}{0.747} \\
\hline & No & $79(51.3)$ & \\
\hline \multirow{2}{*}{$\begin{array}{c}\text { Blood Pressure } \\
\text { controlled }\end{array}$} & Yes & $84(53.9)$ & \multirow{2}{*}{0.334} \\
\hline & No & $70(46.1)$ & \\
\hline
\end{tabular}

\section{DISCUSSION}

Our study assessed the prevalence of other associated cardiovascular risk factors among hypertensive patients. We found high prevalence of obesity, family history of hypertension, taking high fat diet, alcoholism and less physical activity. In our study, among hypertensive patients (29\%) were in age group between 45-55 years and 65 years and above whereas WHO study $1996^{9}$ showed $30 \%$ in above $30 y$ rs and $14.19 \%$ among young adults. Higher portion of study population were female.

In Asian countries, the prevalence of overweight and obesity is increasing. Particularly, a moderate increase in body mass index, makes South Asians more prone to develop non communicable diseases like diabetes and other related diseases. ${ }^{11}$ Our study found $70.8 \%$ of the study populations were obese according to their Body Mass Index (BMI) which also put them at risk of developing cardiovascular disease which is also higher than the study of Republic of Belarus among hypertensive patients $32 \%{ }^{13}$, and in general population in Patna $31.94 \%{ }^{14}$ and among medical students of Nepal $21 \%{ }^{15}$ and study done in Banepa Kavre Nepal showed $54.4 \%{ }^{16}$.

Similarly, this study showed that $46.8 \%$ had habits of taking high salt diet which increase the risk of developing cardiovascular diseases. Smoking is one of the most important modifiable risk factors for increasing cardiovascular disease. In our study, the prevalence of current cigarette smoking was $42.9 \%$ which was higher than the study done in Belarus (31\%) ${ }^{13}$ among hypertensive patients and study done among Nepali medical students $22 \%{ }^{15}$ and in Patna $12.5 \% .^{14}$

This study found that $64.9 \%$ of the hypertensive patients were taking alcohol which was significantly higher. The Joint National Committe (JNC) $7^{17}$ recommends that patients should involve themselves in aerobic exercise for at least 30 minutes per day on most days of the week. This study showed more than half $(64 \%)$ of the respodants had habits of doing regular exercise.

INTERHEART study ${ }^{18}$, a global multicentre case control study, in which from Nepal 244 cases and 239 controls were included, demonstrated abnormal lipids, smoking, hypertension, diabetes, abdominal obesity, psychosocial factors, less consumption of fruits and vegetables, alcohol consumption and physical inactivity as important risk 
factors. Nationwide 2007 noncommunicable disease Risk Factor Survey ${ }^{19}$ and other smaller studies ${ }^{20}$ have demonstrated many of these as major risk factors. Similarly in our study cardiovascular risk factors such as obesity, physical inactivity, alcohol consumption and

\section{REFERENCES}

1. World Health Organization World Health Statistics 2012. Geneva, Switzerland:

2. Yusuf S, Reddy S, Ounpuu S, Anand S. Global burden of cardiovascular diseases, part I: general considerations, the epidemiologic transition, risk factors, and impact of urbanization. Circulation.2001;104:2746 -2753. http://dx.doi. org/10.1161/hc4601.099487

3. Vorster HH. The emergence of cardiovascular disease during urbanisation of Africans. Pub Health Nutr. 2002;5:239 -243. http://dx.doi. org/10.1079/PHN2001299

4. Reddy KS, Yusuf S. Emerging epidemic of cardiovascular disease in developing countries. Circulation. 1998;97:596-601. http://dx.doi. org/10.1161/01.CIR.97.6.596

5. Huxley R, Barzi F, Lam TH, Lawes C, Woo Wong J, Woodward W. The impact of cardiovascular risk factors on the age-related excess risk of coronary heart disease. Int Epidemiol. 2006;35:1025-1033. http://dx.doi.org/10.1093/ije/dy1058

6. Cardiovascular diseases on a global scale: No longer a disease of the rich.[online] 2011 [cited 2011 Aug 20]. Available fromURL:http://theheart. org/article/45381.do

7. Chandalia M, Abate N, Garg A, Stray-Gundersen J, Grundy SM. Relationship between generalized and upper body obesity to insulin resistance in Asian Indian men. J Clin EndocrinolMetab. 1999;84:2329-2335.

8. Xu F, Ah Tse L, Yin X, Yu IT, Griffiths S. Impact of socio-economic factors on stroke prevalence among urban and rural residents in Mainland China. BMC Public Health. 2008;8:170 -179. http://dx.doi.org/10.1186/1471-2458-8-170 habit of high fat intake were significantly higher among the hypertensive patient.

This study was done in small scale so it suggests for further analytical study in large scale.

9. Matriniuk ALC, Lee CMY, Lawes CMM, Ueshima H, Suh I, Lam TH et.al. Hypertension: its prevalence and population-attributable fraction for mortality from cardiovascular disease in the AsiaPacific region. J Hypertens. 2007;25:73-79. http:// dx.doi.org/10.1097/HJH.0b013e328010775f

10. Matriniuk ALC, Lee CMY, Lam TH, Huxley R, Suh I, Jamrozik K et.al. The fraction of ischaemic heart disease and stroke attributable to smoking in the WHO Western Pacific and South-East Asian regions. Tob Control 2006;15:181-188. http:// dx.doi.org/10.1136/tc.2005.013284

11. Ueshima H, Akira S, Katsuyuki M, Tanvir C, Naoyuki. Cardiovascular Disease and Risk Factors in Asia : A Selected Review. Circulation. 2008;118:2702-2709 http://dx.doi.org/10.1161/ CIRCULATIONAHA.108.790048

12. World Health Organization, Global Health Risks: Mortality and Burden of Disease Attributable to Selected Major Risk, World Health Organization, Geneva, Switzerland, 2009.

13. V Paulava, T Nechesova, M Liventseva, I Korobko, T Pavlovich, M Belskaya. Prevalence of cardiovascular risk factors in hypertensive patients in Belarus. Journal of hypertension 2010;28:e-448. http://dx.doi.org/10.1097/01. hjh.0000379656.70814.1e

14. Singh R,MukherjeeM,Kumar R, Singh R, Pal R.Study of Risk factors of Coronary Heart Disease in Urban Slums of Patna. Nepal Journal of Epidemiology 2012;2(3): 205-12 http://dx.doi. org/10.3126/nje.v2i3.6902

15. Giri S, Sharma SR, Timalsina S, Yadav V, Koirala S,Kumar A et.al. Cardiovascular Health Risk Behavior among Medical Students in a Teaching Hospital. J Nepal Health Res Counc 2012;10 (22) :187-91 
16. Manandhar K, Koju R, Sinha NP, Humagain $\mathrm{S}$.Prevalence and Associated Risk Factors of Hypertension Among People Aged 50 years and more in Banepa Municipality, Nepal. Kathmandu university medical journal. 2012;10 (3):35-38

17. Chobanian AV, Bakris GL, Black HR Cushman WC,Green LA, Izzo JL, et al. The seventh report of the Joint National Committee on Prevention, Detection, Evaluation, and Treatment of High Blood Pressure: the JNC 7 report. Journal of American medical association 2003; 289: 2560 2572. http://dx.doi.org/10.1001/jama.289.19.2560

18. Yusuf S, Hawken S, Ounpuu S, Dans T, Avezum A, Lanas F et al. INTERHEART Study Investigators. Effect of potentially modifiable risk factors associated with myocardial infarction in 52 countries (the INTERHEART study): case-control study. Lancet 2004;364:937-52. http://dx.doi. org/10.1016/S0140-6736(04)17018-9

19. Ministry of Health and Population. Nepal NonCommunicable Diseases Risk Factors Survey 2007. Kathmandu, Nepal: Ministry of Health and Population, 2009

20. Vaidya A. Tackling cardiovascular health and disease in Nepal: epidemiology, strategies and implementation. Heart Asia 2011;3:1 87-91 